\title{
Studies and performance of a garlic planter in Uttar Pradesh
}

\section{DEVESH KUMAR, JITENDRA KUMAR AND KAMAL KANT}

See end of the Paper for authors' affiliation

Correspondence to :

\section{DEVESH KUMAR}

Department of Farm Machinery and Power Engineering, Sam Higginbottom University of Agriculture Technology and Sciences, ALLAHABAD (U.P.) INDIA
- ABSTRACT : The main concept of design and development of garlic planter is fabrication, the drilling planter and its metering device are simple in their structure and easy to manufacture. This study followed research after the 3 types of garlic planter was fabricated in 2001 which included; 1) inclined metering plate garlic planter, 2) vertical metering plate garlic planter and 3) spring plate garlic planter. In this study, 2 model were constructed which included; 1) The vertical metering plate with triangular grooves and 2) The bucket type garlic planter. The uniformity of metering system test for the 2 models, the bucket type garlic planter presented the most impressive results. The percentage of broken was very low, about 0.25 per cent. The new prototype garlic planter had 10 rows and was attached to 5 HP power tiller. The garlic planter was tested under actual field conditions at meeting district, Allahabad. The result indicated that the optimum width of garlic planter was 0.9 meter or 9 rows. The suitable soil condition was dry soil. Farmer should apply water after planting. The maximum forward speed was $3 \mathrm{~km} / \mathrm{hr}$ and wheel skid was high about 24.34 per cent. The average depth and width of planting was $2.65 \mathrm{~cm}$. and $4.68 \mathrm{~cm}$. Time for turning at head land was 39 seconds. The field capacity was $0.32 \mathrm{ha} / \mathrm{hr}$ and there were three operators. Hence, the capacity of planter was $0.84 \mathrm{ha} . / \mathrm{man} / \mathrm{day}$.

- KEY WORDS : Garlic planter, Drill planter, Metering device, Bucket metering, Hopper, Measuring instruments

- HOW TO CITE THIS PAPER : Kumar, Devesh, Kumar, Jitendra and Kant, Kamal (2017). Studies and performance of a garlic planter in Uttar Pradesh. Internat. J. Agric. Engg., 10(1) : 227-232, DOI: 10.15740/ HAS/IJAE/10.1/227-232. 